F. Reprod. Fert. (1968) 16, 7-14

\title{
EXPERIMENTS ON SEX GONTROL BY ELEGTROPHORETIG SEPARATION OF SPERMATOZOA IN THE RABBIT
}

\author{
AFIF SEVINÇ* \\ Animal Reproduction Laboratory, Michigan State University, \\ East Lansing, Michigan, U.S.A. \\ (Received 3rd March 1967, revised 22nd May 1967)
}

\begin{abstract}
Summary. Four electrophoretic experiments on rabbit spermatozoa were carried out using Afif, phosphate, Luck's phosphate, AFY, AFYAM and AFAM buffers. A new technique using motile spermatozoa and intermittent electric power was employed with three- and seven-chambered electrophoretic cells.

Two-way migration of spermatozoa was achieved. Sex ratios of offspring resulting from anodic and cathodic spermatozoa diluted in Afif, phosphate and Luck's phosphate buffers in the first experiment were significantly different from the expected normal sex ratio, while the other three experiments, in the main, did not show the same trend.
\end{abstract}

\section{INTRODUCTION}

The first electrophoretic study on separation of X- and Y-chromosomebearing rabbit spermatozoa was reported by Koltzoff \& Schröder (1933). They obtained sex ratios of $100 \%$ male and $80 \%$ female from does inseminated

TABLE 1

DIREGTION OF ELECTROPHORETIC MIGRATION OBSERVED BY VARIOUS AUTHORS

\begin{tabular}{l|l|l}
\hline \multicolumn{1}{c|}{ Author } & Sperm. used & Direction of migration \\
\hline Schröder (1934) & Stallion, rabbit & Two way \\
Lewin (1956) & Human, rabbit & Two way \\
Gordon (1957) & Rabbit & Two way \\
Bangham (1961) & Ram, rabbit & Two way \\
Laird (1964) & Bull & Two way \\
Machowka \& Schegalloff (1935) & Rabbit & Anodic \\
Jöel, Kotchalsky, Kedem \& Sternberg (1951) & Human & Anodic \\
Nevo, Michaeli \& Schindler (1961) & Bull, rabbit & Anodic \\
Pilz (1952) & Bull, rabbit & Cathodic \\
Vesselinovitch (1959) & Bull, rabbit & Cathodic \\
& & \\
\hline
\end{tabular}

with cathode- and anode-migrating spermatozoa, respectively. Later, Schröder (1934) reported $80 \%$ success in controlling sex ratio by electrophoresis. While Kordts (1952) was unable to repeat Schröder's work, Lewin (1956) confirmed

* Present address: A. Ü. Veteriner Fakültesi Zootekni Kürsüsü Doçenti, Ankara, Turkey. 
two-way migration and Gordon (1957) obtained results similar to her findings. The electrophoretic migration of spermatozoa observed by various authors is given in Table 1.

The present work with electrophoresis was carried out mainly to determine the possibility of sex control in the rabbit by separation of X- and Y-chromosome-bearing spermatozoa. Preliminary studies were made to find out the optimal buffer, temperature, $\mathrm{pH}$ and electric power. Furthermore, the electrophoretic behaviour and migrating direction of motile, washed and unwashed dead rabbit and bull spermatozoa were examined under the microscope using a Northrop-Kunitz micro-electrophoretic apparatus.

\section{MATERIALS AND METHODS}

A total of four experiments was carried out using $V$-shaped electrophoretic cells having agar gel stoppers between each electrode and its related lateral chamber. The three-chambered cell was used in the first three experiments, and the seven-chambered cell was used in the last experiment (Text-fig. 1).
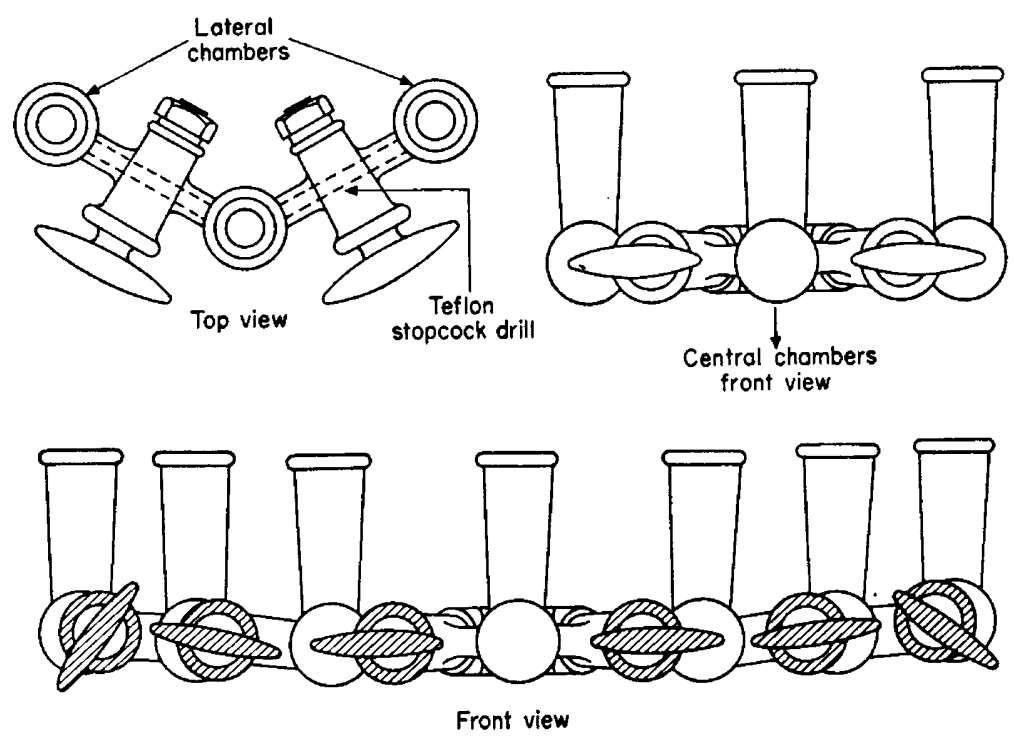

TEXT-FIG. 1.

The volumes of each chamber and each stopcock of the three-chambered cell were about 3 and $0.3 \mathrm{ml}$; and the volumes of the central chamber, each lateral chamber and each stopcock of the seven-chambered cell were about 7.5, 3.5 and $0.45 \mathrm{ml}$ respectively. A glass tube containing agar gel was inserted in each counter tube of the lateral chambers after filling the cell with buffer. The cell was held in a regulated water bath to control temperature. Electric power was provided through a Heathkit-Model IP-32 regulated power supply and was applied in two different intensities and frequencies in all electrophoretic runs. Buffers, electric powers, time intervals, temperatures, average semen volumes, rabbits inseminated from each run and bucks used in each experiment are given 


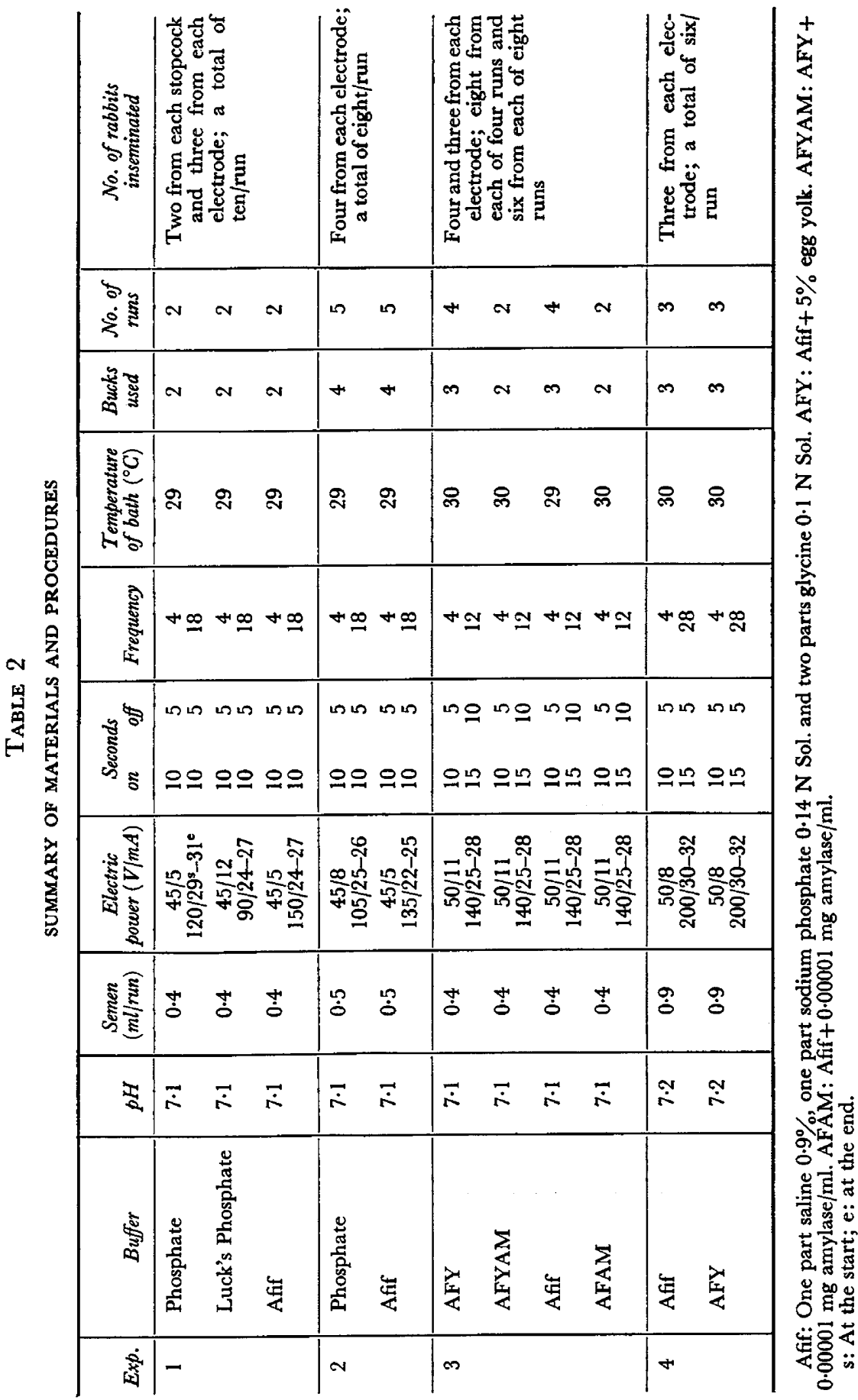


in Table 2. Sperm concentrations were determined by a haemocytometer for each ejaculate before electrophoresis and for each electrodic chamber after electrophoresis. Each rabbit was given an intravenous injection of 20 i.u. $\mathbf{L H}$ about $1 \mathrm{hr}$ before insemination. Inseminating doses varied from 0.5 to $1.0 \mathrm{ml}$ with sperm concentrations ranging from $75 \times 10^{3}$ to $3 \times 10^{6}$. The sex of dayold offspring was scored histologically in the first two experiments and macroscopically in the others.

\section{RESULTS AND DISCUSSION}

The number of litters and sex of day-old rabbits in all experiments are given in Tables 3, 4, 5 and 6 . The distribution of litters related to phosphate, Luck's phosphate and Afif buffers, and to anode, anode stopcock, cathode stopcock and cathode were $2,3,4,6 ; 0,4,3,4 ;$ and $4,2,4,6$, respectively. The average

TABLE 3

RESULTS OF THE FIRST EXPERIMENT

\begin{tabular}{|c|c|c|c|c|c|}
\hline \multirow[t]{2}{*}{ Litter } & \multirow[t]{2}{*}{ Buffer } & Anode & $\begin{array}{c}\text { Anode } \\
\text { stopcock }\end{array}$ & $\begin{array}{l}\text { Cathode } \\
\text { stopcock }\end{array}$ & Cathode \\
\hline & & $F \quad M$ & $F \quad M$ & $F \quad M$ & $F$ \\
\hline $\begin{array}{c}1 \\
2 \\
3 \\
4 \\
5 \\
6 \\
\text { Total } \% \\
\text { Male } \%\end{array}$ & Phosphate & 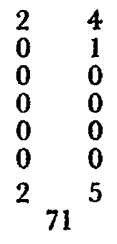 & \begin{tabular}{lr}
1 & 0 \\
0 & 4 \\
5 & 1 \\
0 & 0 \\
0 & 0 \\
0 & 0 \\
6 & \\
\multicolumn{2}{l}{45}
\end{tabular} & 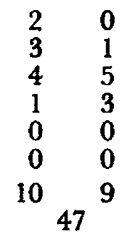 & \begin{tabular}{rr}
0 & 1 \\
1 & 1 \\
5 & 2 \\
2 & 3 \\
4 & 2 \\
3 & 1 \\
15 & 10 \\
\multicolumn{2}{|c}{40}
\end{tabular} \\
\hline $\begin{array}{r}1 \\
2 \\
3 \\
4 \\
\text { Total } \\
\text { Male \% }\end{array}$ & Luck's phosphate & 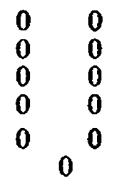 & $\begin{array}{lr}3 & 2 \\
1 & 3 \\
2 & 0 \\
2 & 2 \\
8 & 7 \\
& \\
& 47\end{array}$ & $\begin{array}{rrr}3 & 4 \\
4 & & 1 \\
3 & & 1 \\
0 & & 0 \\
10 & & 6 \\
& 38 & \end{array}$ & $\begin{array}{rr}0 & 2 \\
2 & 1 \\
5 & 1 \\
4 & 2 \\
11 & \\
& 35\end{array}$ \\
\hline $\begin{array}{r}1 \\
2 \\
3 \\
4 \\
5 \\
\text { Total } \\
\text { Male \% }\end{array}$ & Afif & \begin{tabular}{lr}
0 & 4 \\
0 & 3 \\
1 & 3 \\
1 & 0 \\
0 & 0 \\
2 & 10 \\
\multicolumn{2}{c}{$\mathbf{8 3}$}
\end{tabular} & \begin{tabular}{ll}
2 & 1 \\
1 & 2 \\
0 & 0 \\
0 & 0 \\
0 & 0 \\
3 & \\
\multicolumn{2}{l}{50}
\end{tabular} & \begin{tabular}{rr}
3 & 4 \\
4 & 3 \\
1 & 3 \\
5 & 4 \\
0 & 0 \\
13 & 14 \\
\multicolumn{1}{r}{52} &
\end{tabular} & \begin{tabular}{rr}
3 & 5 \\
5 & 1 \\
0 & 1 \\
6 & 3 \\
2 & 0 \\
16 & 10 \\
\multicolumn{2}{c}{39}
\end{tabular} \\
\hline $\begin{array}{l}\text { Total } \\
\text { Male } \%\end{array}$ & & $47^{15}$ & ${ }_{47}^{15}$ & ${ }^{33} 47^{29}$ & $4238^{26}$ \\
\hline
\end{tabular}

percentages of males for all buffers resulting from anode-, anode stopcock-, cathode stopcock- and cathode-migrating spermatozoa were 79, 47, 47 and 38, respectively.

The average litter size and fertility rate were 4.1 and $75 \%$ for phosphate, 4.3 and $55 \%$ for Luck's phosphate and 4.7 and $75 \%$ for Afif buffer. The motility and viability of rabbit spermatozoa were found to be very satisfactory after they had been subjected to electrophoresis. The same results were obtained with bull 
spermatozoa and they proved to withstand freezing at $-79^{\circ} \mathrm{C}$ (Sevinç, Boyd, Kirton \& Hafs, unpublished observations).

The difference between the expected normal sex ratio and the sex ratios of offspring obtained from anodic and cathodic spermatozoa for all buffers was highly significant $(P<0 \cdot 005)$. There was no deviation between the expected normal sex ratio and the sex ratios of offspring born from inseminations of anodic and cathodic stopcock spermatozoa. Rabbits inseminated with anodemigrating spermatozoa gave litters predominantly of males while litters obtained from cathodic spermatozoa were predominantly females. The most favourable results, including litter size and fertility rate, were achieved with Afif buffer (Table 3).

TABLE 4

RESULTS OF THE SECOND EXPERIMENT

\begin{tabular}{|c|c|c|c|c|}
\hline \multirow{4}{*}{ Litter } & \multicolumn{4}{|c|}{ Buffer } \\
\hline & \multicolumn{2}{|c|}{ Phosphate } & \multicolumn{2}{|c|}{$A f f$} \\
\hline & Anode & Cathode & Anode & Cathode \\
\hline & F $\quad M$ & $F \quad \boldsymbol{N}$ & $F \quad M$ & $F \quad M$ \\
\hline $\begin{array}{r}1 \\
2 \\
3 \\
4 \\
5 \\
6 \\
7 \\
8 \\
9 \\
10 \\
11 \\
12 \\
13\end{array}$ & $\begin{array}{ll}0 & 1 \\
0 & \mathbf{3} \\
\mathbf{4} & 2 \\
\mathbf{3} & 1 \\
\mathbf{3} & 0 \\
1 & \mathbf{3} \\
\mathbf{3} & 1 \\
3 & 4 \\
\mathbf{4} & 5 \\
\mathbf{3} & \mathbf{3} \\
\mathbf{1} & 1 \\
\mathbf{0} & 0 \\
\mathbf{0} & 0\end{array}$ & $\begin{array}{ll}5 & 2 \\
2 & 1 \\
4 & 4 \\
3 & 1 \\
4 & 2 \\
3 & 3 \\
3 & 3 \\
3 & 7 \\
3 & 3 \\
2 & 1 \\
2 & 4 \\
0 & 0 \\
0 & 0\end{array}$ & $\begin{array}{ll}1 & 2 \\
3 & 2 \\
2 & 3 \\
1 & 5 \\
1 & 2 \\
0 & 1 \\
5 & 1 \\
2 & 2 \\
2 & 3 \\
0 & 0 \\
0 & 0 \\
0 & 0 \\
0 & 0\end{array}$ & $\begin{array}{ll}1 & 2 \\
2 & 3 \\
3 & 4 \\
1 & 1 \\
1 & 2 \\
4 & 1 \\
2 & 6 \\
4 & 4 \\
4 & 3 \\
3 & 5 \\
1 & 2 \\
1 & 6 \\
7 & 4\end{array}$ \\
\hline \multirow[t]{4}{*}{$\begin{array}{l}\text { Total } \\
\text { Male } \%\end{array}$} & ${ }^{25} 48.9^{24}$ & $\begin{array}{c}34 \underset{47}{31} \\
4.7\end{array}$ & $17 \underset{55 \cdot 3}{21}$ & $34 \begin{array}{c}43 \\
55 \cdot 8\end{array}$ \\
\hline & & Anode & Cathode & \\
\hline & & $F \quad \lambda$ & $F \quad M$ & \\
\hline & $\begin{array}{l}\text { Total } \\
\text { Male \% }\end{array}$ & ${ }_{51 \cdot 7^{4}}^{4}$ & ${ }_{52 \cdot 1}^{68} 74$ & \\
\hline
\end{tabular}

The results of the second experiment were not similar to those of the first (Table 4). Sex ratios of offspring born from inseminations of anodic and cathodic spermatozoa subjected to electrophoresis in phosphate buffer were almost the same as the expected normal sex ratio. The sex ratio of those born from spermatozoa treated in Afif buffer showed a preponderance of males. The average fertility rate and litter size were about the same as in the first experiment.

Sex ratios of offspring in the third experiment using AFY, AFYAM, Afif and AFAM buffers were somewhat different from each other and also from those of the preceding experiments (Table 5). In this experiment, the sex ratios of 
offspring born from anodic and cathodic spermatozoa treated in AFAM buffer were the only ones significantly different from the expected normal sex ratio.

The average fertility rate and offspring/litter in this experiment were satisfactory for all buffer combinations except AFAM, and were generally higher than those of the preceding experiments. Finally, sex ratios of offspring derived from spermatozoa at either electrode in the fourth experiment showed a preponderance of males (Table 6). The average fertility rate and offspring/litter in this experiment were $61 \%$ and 5 for Aff buffer, and $83 \%$ and 4.85 for AFY buffer.

TABLE 5

RESULTS OF THE THIRD EXPERIMENT

\begin{tabular}{|c|c|c|c|c|c|c|c|c|c|c|c|c|c|c|c|c|}
\hline \multirow{4}{*}{ Litter } & \multicolumn{16}{|c|}{ Buffer } \\
\hline & \multicolumn{4}{|c|}{$A F r$} & \multicolumn{4}{|c|}{$A F Y A M$} & \multicolumn{4}{|c|}{ Afif } & \multicolumn{4}{|c|}{$A F A M$} \\
\hline & \multicolumn{2}{|c|}{ Anode } & \multicolumn{2}{|c|}{ Cathode } & \multicolumn{2}{|c|}{ Anode } & \multicolumn{2}{|c|}{ Cathode } & \multicolumn{2}{|c|}{ Anode } & \multicolumn{2}{|c|}{ Cathode } & \multicolumn{2}{|c|}{ Anode } & \multicolumn{2}{|c|}{ Cathode } \\
\hline & $F$ & $M$ & $F$ & $M$ & $F$ & $M$ & $F$ & $M$ & $F$ & $M$ & $F$ & $M$ & $F$ & $M$ & & $M$ \\
\hline $\begin{array}{r}1 \\
2 \\
3 \\
4 \\
5 \\
6 \\
7 \\
8 \\
9 \\
10 \\
11\end{array}$ & $\begin{array}{l}1 \\
4 \\
4 \\
1 \\
3 \\
3 \\
1 \\
4 \\
1 \\
0 \\
0\end{array}$ & $\begin{array}{l}5 \\
1 \\
2 \\
1 \\
6 \\
2 \\
5 \\
4 \\
5 \\
0 \\
0\end{array}$ & $\begin{array}{l}4 \\
1 \\
2 \\
5 \\
2 \\
0 \\
1 \\
2 \\
0 \\
0 \\
0\end{array}$ & $\begin{array}{l}4 \\
4 \\
1 \\
0 \\
4 \\
3 \\
1 \\
1 \\
0 \\
0 \\
0\end{array}$ & $\begin{array}{l}4 \\
3 \\
1 \\
3 \\
4 \\
3 \\
0 \\
0 \\
0 \\
0 \\
0\end{array}$ & $\begin{array}{l}1 \\
2 \\
6 \\
4 \\
0 \\
4 \\
0 \\
0 \\
0 \\
0 \\
0\end{array}$ & $\begin{array}{l}2 \\
1 \\
1 \\
5 \\
4 \\
0 \\
0 \\
0 \\
0 \\
0 \\
0\end{array}$ & $\begin{array}{l}4 \\
2 \\
5 \\
3 \\
3 \\
3 \\
3 \\
1 \\
0 \\
0 \\
0\end{array}$ & $\begin{array}{l}2 \\
4 \\
4 \\
1 \\
4 \\
1 \\
1 \\
2 \\
2 \\
4 \\
2\end{array}$ & $\begin{array}{l}2 \\
1 \\
4 \\
4 \\
1 \\
3 \\
1 \\
5 \\
4 \\
0 \\
3\end{array}$ & $\begin{array}{l}1 \\
3 \\
1 \\
3 \\
2 \\
0 \\
0 \\
5 \\
5 \\
4 \\
0\end{array}$ & $\begin{array}{l}0 \\
0 \\
1 \\
5 \\
4 \\
2 \\
2 \\
3 \\
1 \\
4 \\
0\end{array}$ & $\begin{array}{l}1 \\
1 \\
0 \\
0 \\
0 \\
0 \\
0 \\
0 \\
0 \\
0 \\
0\end{array}$ & $\begin{array}{l}2 \\
1 \\
1 \\
2 \\
0 \\
0 \\
0 \\
0 \\
0 \\
0 \\
0\end{array}$ & & $\begin{array}{l}2 \\
1 \\
2 \\
1 \\
3 \\
0 \\
0 \\
0 \\
0 \\
0 \\
0\end{array}$ \\
\hline $\begin{array}{l}\text { Total } \\
\text { Male \% }\end{array}$ & ${ }^{22} 58$ & & ${ }^{17} 5$ & & ${ }_{48}^{18}$ & & ${ }^{13} 64$ & & ${ }^{27} 50$ & & 24 & & ${ }^{2} 75$ & & & $12.9^{9}$ \\
\hline
\end{tabular}

\begin{tabular}{l|cr|cr}
\hline \multirow{2}{*}{} & \multicolumn{2}{|c|}{ Anode } & \multicolumn{2}{|c}{ Cathode } \\
\cline { 2 - 3 } & $F$ & $M$ & $F$ & $M$ \\
\hline Total & 69.82 & \multicolumn{2}{|c}{$66^{73}$} \\
Male $\%$ & $54 \cdot 3$ & \multicolumn{2}{|c}{$52 \cdot 5$} \\
\hline
\end{tabular}

The preponderance of males and females for anodic and cathodic litters reported by Schröder (1934) and Gordon (1957) is in disagreement with the present results. This contradiction is probably due to a reverse definition of the electrodes.

The first experiment shows a highly significant separation of $\mathrm{X}$ - and $\mathrm{Y}$ chromosome-bearing spermatozoa. On the other hand, the extent of biological variation, and the limited number of litters obtained from each type of electrodic spermatozoa do not favour a generalization of the preceding conclusion. In fact, the second, third and fourth experiments did not substantiate the results 
of the first experiment. Although the sex ratios of offspring from spermatozoa subjected to electrophoresis in AFAM buffer in the third experiment agreed with those in the first experiment, other results of the third experiment were quite different.

Deviations from the expected normal sex ratio and the preponderance of male and female offspring in anodic and cathodic litters suggest that rabbit spermatozoa might have different electric charges. The results of the first experiment, and the preponderance of males with Aff buffer and of females with phosphate buffer may indicate a charge difference between $\mathrm{X}$ - and $\mathrm{Y}$-chromosome-bearing spermatozoa.

TABLE 6

RESULTS OF THE FOURTH EXPERIMENT

\begin{tabular}{|c|c|c|c|c|c|c|c|c|}
\hline \multirow{4}{*}{ Litter } & \multicolumn{8}{|c|}{ Buffer } \\
\hline & \multicolumn{4}{|c|}{ Afif } & \multicolumn{4}{|c|}{$A F Y$} \\
\hline & \multicolumn{2}{|c|}{ Anode } & \multicolumn{2}{|c|}{ Cathode } & \multicolumn{2}{|c|}{ Anode } & \multicolumn{2}{|c|}{ Cathode } \\
\hline & $F$ & $M$ & $F$ & $M$ & $F$ & $M$ & $F$ & $M$ \\
\hline $\begin{array}{l}1 \\
2 \\
3 \\
4 \\
5 \\
6 \\
7 \\
8\end{array}$ & $\begin{array}{l}3 \\
3 \\
1 \\
2 \\
0 \\
0 \\
0 \\
0\end{array}$ & $\begin{array}{l}4 \\
1 \\
4 \\
4 \\
0 \\
0 \\
0 \\
0\end{array}$ & $\begin{array}{l}4 \\
0 \\
3 \\
2 \\
1 \\
3 \\
2 \\
0\end{array}$ & $\begin{array}{l}1 \\
4 \\
1 \\
2 \\
7 \\
4 \\
0 \\
0\end{array}$ & $\begin{array}{l}2 \\
3 \\
1 \\
1 \\
5 \\
1 \\
1 \\
4\end{array}$ & $\begin{array}{l}3 \\
6 \\
5 \\
1 \\
4 \\
4 \\
0 \\
2\end{array}$ & $\begin{array}{l}1 \\
3 \\
2 \\
2 \\
3 \\
3 \\
2 \\
0\end{array}$ & $\begin{array}{l}2 \\
4 \\
4 \\
3 \\
5 \\
1 \\
4 \\
0\end{array}$ \\
\hline $\begin{array}{l}\text { Total } \\
\text { Male \% }\end{array}$ & $\begin{array}{lr}9 & 1 \\
59 \cdot 0\end{array}$ & & ${ }^{15} 55$ & & $\begin{array}{l}18 \\
58 .\end{array}$ & & $\begin{array}{l}16 \\
59\end{array}$ & \\
\hline
\end{tabular}

\begin{tabular}{l|cc|cc}
\hline & \multicolumn{2}{|c|}{ Anode } & \multicolumn{2}{|c}{ Cathode } \\
\cline { 2 - 4 } & $F$ & $M$ & $F$ & $M$ \\
\hline Total & 27 & 38 & 31 & 42 \\
Male $\%$ & \multicolumn{2}{|c|}{58.5} & \multicolumn{2}{|c}{57.5} \\
\hline
\end{tabular}

From the available literature and the present study, it is not possible either to accept or reject with certainty the theory of separation of X- and Y-chromosome-bearing spermatozoa according to their different electric charges. All variables involved in electrophoretic separation of spermatozoa, such as buffer, type of electrophoretic cell, $\mathrm{pH}$, kinetic field strength, temperature, electrolytic changes during electrophoresis and the relationship of spermatozoa to seminal plasma, should be investigated in detail to help in the planning of experiments.

\section{ACKNOWLEDGMENTS}

I would like to express my appreciation to the Fulbright Commission in Washington for the fellowship granted to me, and to Dr Harold D. Hafs for his valuable suggestions and for the laboratory facilities which made this study possible. 


\section{REFERENCES}

Bangham, A. D. (1961) Electrophoretic characteristics of ram and rabbit spermatozoa. Proc. R. Soc. B, $155,292$.

Gordon, M. J. (1957) Control of sex ratio in rabbits by electrophoresis of spermatozoa. Proc. natn. Acad. Sci. U.S.A. 43, 913.

Jöel, C. A., Kotchalsky, A., Kedem, O. \& Sterneerg, N. (1951) Electrophoresis of human spermatozoa. Experientia, 7, 274.

Koltzofr, N. K. \& Schröder, V. N. (1933) Artificial control of sex in the progeny of mammals. Nature, Lond. 131, 329.

KoRDrs, E. (1952) Investigations on the suitability of electrophoresis for the separation of $X$ and $Y$ bearing spermatozoa in the rabbit, and a re-examination of the findings of Vera Schröder. Anim. Breed. Abstr. 21, 178.

LAIRD, G. W. (1964) Dimorphisms observed in bovine sperm cells and electrophoretic separation of types. Fert. Steril. 15, 675.

LewIN, S. (1956) Artificial sex regulation of mammalian offspring. Br. vet. F. 112, 549.

MachowKa, W. W. \& Schrgallorp, S. B. (1935) The reaction of spermatozoa to direct current. Arch. EntwMech. Org., 133, 694.

Nevo, A. G., Michaeli, I. \& Schindier, H. (1961) Electrophoretic properties of bull and of rabbit spermatozoa. Expl Cell Res. 23, 69.

Pilz, A. (1952) Das Verhalten der Saugetierspermien im elektrischen Feld. Z. Tierzucht. ZuchtBiol. 60, 315.

SCHRöDER, V. N. (1934) Physico-chemical analysis of the physiology of spermatozoa. V. Artificial control of sex in mammals. (Abstract). Anim. Breed. Abstr. 3, 166.

Vesselinovitch, S. D. (1959) Microelectrophoresis of bovine spermatozoa. Cornell Vet. 49, 359. 